\title{
Micromonospora coriariae sp. nov., isolated from root nodules of Coriaria myrtifolia
}

\author{
Martha E. Trujillo, ${ }^{1}$ Reiner M. Kroppenstedt, ${ }^{2}$ Peter Schumann, ${ }^{2}$ \\ Lorena Carro $^{1}$ and Eustoquio Martínez-Molina ${ }^{1}$ \\ ${ }^{1}$ Departamento de Microbiología y Genética, Edificio Departamental, Lab. 209, Campus Miguel \\ de Unamuno, Universidad de Salamanca, 37007 Salamanca, Spain
}

Correspondence

Martha E. Trujillo

mett@usal.es
${ }^{2} \mathrm{DSMZ}$ - Deutsche Sammlung von Mikroorganismen und Zellkulturen GmbH, Mascheroder Weg 1b, 38124 Braunschweig, Germany
An actinomycete strain, $\mathrm{NAR01}{ }^{\top}$, was isolated from root nodules of a Coriaria plant. The $16 \mathrm{~S}$ rRNA gene sequence of strain NARO $1^{\top}$ showed most similarity to the type strains of Micromonospora endolithica (98.94\%) and Micromonospora chersina (98.4\%). The chemotaxonomic results obtained confirmed the taxonomic position of the isolate within the genus Micromonospora, and revealed differences at the species level. Physiological and biochemical tests showed that strain NARO $1^{\top}$ could be clearly distinguished from its closest phylogenetic neighbours, while DNA-DNA hybridization results indicated that the isolate represents a novel species. On the basis of these results, strain NAR01 ${ }^{\top}\left(=\mathrm{DSM} 44875^{\top}=\mathrm{LMG} 23557^{\top}\right)$ is proposed as the type strain of the novel species Micromonospora coriariae sp. nov.
The number of novel species of Micromonospora Ørskov 1923 described has increased significantly in the last year (Kroppenstedt et al., 2005; Thawai et al., 2005a, b; Trujillo et al., 2005) and the genus currently holds 27 species with validly published names. While most strains have been isolated from soil collected in diverse geographical regions, members of the genus Micromonospora also appear to be closely associated with plant roots (Coombs \& Franco, 2003; Valdés et al., 2005; M. E. Trujillo, unpublished observations). In the present paper, we report on the isolation of a novel Micromonospora strain, $\mathrm{NAR}^{\mathrm{T}}{ }^{\mathrm{T}}$, from surfacesterilized, nitrogen-fixing root nodules obtained from the plant Coriaria myrtifolia, which was collected in Salamanca, Spain.

The root nodules used for the isolation of strain $\mathrm{NAR}_{01}{ }^{\mathrm{T}}$ were washed several times with sterile distilled water and were then surface sterilized in $\mathrm{HgCl}_{2}(2 \cdot 5 \% \mathrm{w} / \mathrm{v})$ for $2 \mathrm{~min}$. The nodules were rinsed several times with sterile distilled water and then crushed using a sterile glass rod. The homogenized plant tissue was inoculated onto yeast extract/ mannitol agar (Vincent, 1970) and the plates were incubated at $28^{\circ} \mathrm{C}$ for 10 days. The isolation plates were then examined under a stereoscopic microscope: several small orange colonies were readily observed. Strain NAR $01^{\mathrm{T}}$ was selected because of its capacity to degrade xylan, as shown by the

The GenBank/EMBL/DDBJ accession number for the 16S rRNA gene sequence of strain $\mathrm{NARO1}^{\top}$ is AJ784008.

An extended phylogenetic tree and the cellular fatty acid profile of strain $N A R O 1^{\top}$ are available as supplementary data in IJSEM Online. ability of the micro-organism to grow on XED medium (Rivas et al., 2003), which contained this carbohydrate as the sole carbon source.

The cultural characteristics of strain $\mathrm{NAR} 01^{\mathrm{T}}$ were studied on several media, namely yeast extract-malt extract agar (ISP 2), Bennett's agar (Jones, 1949), oatmeal agar (ISP 3), SA1 agar (Trujillo et al., 2005) and yeast extract/mannitol agar. Abundant growth was observed on Bennett's, ISP 2 and SA1 agars, while moderate growth was obtained on ISP 3 and yeast extract/mannitol agar media. Colonies were an intense orange colour, folded and raised, turning darker after 3 weeks; neither aerial hyphae nor diffusible pigments were produced. Differences in substrate-mycelium colour found between $\mathrm{NAR}^{\mathrm{T}} \mathrm{T}^{\mathrm{a}}$ and Micromonospora species are presented in Table 1.

Phase-contrast observations (Opti-Phot microscope, $\times 100$; Nikon) were performed using cells obtained after 5 days incubation in liquid medium. The strain produced branched hyphae with terminal spores on both short and long side branches. The shape of the spores produced by strain $\mathrm{NAR} 01^{\mathrm{T}}$ was very similar to that reported by Hirsch et al. (2004) for Micromonospora endolithica. Gram staining (Doetsch, 1981) was performed using 3-day-old cultures: strain $\mathrm{NAR}_{01}^{\mathrm{T}}$ was Gram-positive.

Extraction of genomic DNA, PCR amplification of the 16S rRNA gene and sequencing of the purified PCR products were performed as described previously (Rivas et al., 2003). The sequence of strain $\mathrm{NAR} 01^{\mathrm{T}}$ was manually aligned and compared with other sequences obtained from GenBank/ 
Table 1. Differential characteristics of $\mathrm{NARO}^{\top}$ and phylogenetically related Micromonospora species

Reference strains: 1, M. endolithica DSM 44398 ${ }^{\mathrm{T}}$; 2, M. chersina DSM 44398 ${ }^{\mathrm{T}}$; 3, M. rosaria DSM $803^{\mathrm{T}}$ [data in columns $1-3$ are from Hirsch et al. (2004), except for API ZYM tests, which were carried out in the present study]; 4, M. inositola DSM 43819 ${ }^{\mathrm{T}}$ [data from Kawamoto (1989), except for API ZYM tests, which were carried out in the present study]; 5, M. fulviridis DSM 43906 ${ }^{\mathrm{T}}$; 6, M. echinospora DSM 43816 ${ }^{\mathrm{T}}$; 7, M. sagamiensis DSM 43912 ${ }^{\mathrm{T}}$; 8, M. inyoensis DSM $46123^{\mathrm{T}}$ (data in columns 5-8 from Kroppenstedt et al., 2005). With the exception of M. inositola DSM $43819^{\mathrm{T}}$ and M. fulviridis DSM $43906^{\mathrm{T}}$ (no data available), all the strains were positive for alkaline phosphatase, esterase (C8), leucine arylamidase, cystine arylamidase, acid phosphatase and $\alpha$-glucosidase and negative for $\alpha$-fucosidase. + , Positive; - , negative; ND, not determined; $\mathrm{V}$, variable; $(+)$, growth better than negative control but less than positive control.

\begin{tabular}{|c|c|c|c|c|c|c|c|c|c|}
\hline Characteristic & Strain NAR01 ${ }^{\mathrm{T}}$ & 1 & 2 & 3 & 4 & 5 & 6 & 7 & 8 \\
\hline $\begin{array}{l}\text { Colour of substrate } \\
\text { mycelium (on ISP } 2 \\
\text { medium) }\end{array}$ & $\begin{array}{l}\text { Intense } \\
\text { orange }\end{array}$ & Orange & $\begin{array}{l}\text { Light } \\
\text { yellow }\end{array}$ & $\begin{array}{c}\text { Orange- } \\
\text { brown }\end{array}$ & Orange & $\begin{array}{l}\text { Salmon- } \\
\text { orange }\end{array}$ & Purple & Coral red & Yellow-olive \\
\hline Diffusible pigments & - & - & $\begin{array}{c}\text { Fluorescent } \\
\text { yellow }\end{array}$ & Wine red & - & - & - & - & Yellow \\
\hline Nitrate reduction & + & - & V & - & - & $\mathrm{ND}$ & $\mathrm{V}$ & $\mathrm{ND}$ & $\mathrm{ND}$ \\
\hline Tyrosine hydrolysis & - & + & - & + & $\mathrm{ND}$ & ND & $\mathrm{ND}$ & $\mathrm{ND}$ & $\mathrm{ND}$ \\
\hline Xylan hydrolysis & + & - & - & ND & - & ND & ND & ND & ND \\
\hline \multicolumn{10}{|l|}{ Carbon sources: } \\
\hline Fructose & + & + & ND & ND & ND & + & - & - & $(+)$ \\
\hline Gluconate & + & - & ND & ND & $\mathrm{ND}$ & $\mathrm{ND}$ & ND & $\mathrm{ND}$ & $\mathrm{ND}$ \\
\hline Melibiose & + & + & - & + & + & $\mathrm{ND}$ & - & $\mathrm{ND}$ & $\mathrm{ND}$ \\
\hline Raffinose & + & + & $\mathrm{V}$ & - & $\mathrm{ND}$ & + & + & $(+)$ & $(+)$ \\
\hline Rhamnose & + & - & - & + & - & - & + & - & $(+)$ \\
\hline Ribose & + & - & - & + & - & $\mathrm{ND}$ & - & $\mathrm{ND}$ & $\mathrm{ND}$ \\
\hline Sucrose & - & + & + & + & + & + & + & - & $(+)$ \\
\hline Xylose & + & + & ND & ND & $\mathrm{ND}$ & - & - & - & $(+)$ \\
\hline \multicolumn{10}{|l|}{ API ZYM tests } \\
\hline Esterase (C4) & + & + & + & ND & $\mathrm{ND}$ & + & - & - & + \\
\hline Lipase (C14) & + & - & + & ND & $\mathrm{ND}$ & + & + & - & - \\
\hline Trypsin & + & + & + & ND & ND & - & + & - & + \\
\hline$\alpha$-Chymotrypsin & - & - & + & ND & ND & + & + & - & + \\
\hline$\alpha$-Galactosidase & + & + & + & ND & + & + & - & + & - \\
\hline$\alpha$-Mannosidase & - & - & + & ND & + & - & - & - & - \\
\hline $\begin{array}{l}\text { Maximum } \mathrm{NaCl} \\
\text { tolerance }(\%, \mathrm{w} / \mathrm{v})\end{array}$ & 1 & 7 & 3 & ND & $1 \cdot 5$ & ND & 3 & $\mathrm{ND}$ & $\mathrm{ND}$ \\
\hline Temperature range $\left({ }^{\circ} \mathrm{C}\right)$ & $12-37$ & 8-39 & $18-49$ & $18-42$ & $25-40$ & $\mathrm{ND}$ & $27-37$ & $\mathrm{ND}$ & ND \\
\hline Main menaquinone & MK-10 $\left(\mathrm{H}_{4}\right)$ & $\mathrm{MK}-10\left(\mathrm{H}_{4}\right)$ & MK-9 $\left(\mathrm{H}_{4}\right)$ & MK-10 $\left(\mathrm{H}_{4}\right)$ & MK-10 $\left(\mathrm{H}_{4}\right)$ & MK-9 $\left(\mathrm{H}_{4}\right)$ & MK-10 $\left(\mathrm{H}_{4}\right)$ & MK-9 $\left(\mathrm{H}_{4}\right)$ & MK-9 $\left(\mathrm{H}_{4}\right)$ \\
\hline Whole-cell sugars* & $\begin{array}{l}\text { Glc, Xyl, Ara, } \\
\text { Man, Rib }\end{array}$ & $\begin{array}{l}\text { Gal, Ara, Xyl, } \\
\text { Rib, Rha }\end{array}$ & $\begin{array}{l}\text { Glc, Man, } \\
\text { Xyl, Ara }\end{array}$ & $\begin{array}{l}\text { Ara, Xyl, } \\
\text { Gal }\end{array}$ & ND & Xyl, Glc & Xyl, Glc & Xyl, Glc & $\begin{array}{c}\text { Xyl, Glc, } \\
\text { Ara }\end{array}$ \\
\hline
\end{tabular}

*Ara, Arabinose; Gal, galactose; Glc, glucose; Man, mannose; Rha, rhamnose; Rib, ribose; Xyl, xylose.

EMBL. Phylogenetic distances were calculated with the Kimura two-parameter model, and the tree topologies were inferred using the least-squares (De Soete, 1983), maximum-parsimony (Fitch, 1971) and neighbour-joining methods (Saitou \& Nei, 1987). Bootstrap replications (1000) were performed using the MEGA program as described by Kumar et al. (2001).

An almost-complete $16 \mathrm{~S}$ rRNA gene sequence (1451 nt) was obtained for $\mathrm{NAR}_{0} 1^{\mathrm{T}}$ and compared with those deposited in the public databases. The highest levels of similarity were with M. endolithica DSM $44398^{\mathrm{T}} \quad(98.94 \%)$ and
Micromonospora chersina DSM $44151^{\mathrm{T}}(98 \cdot 4 \%)$. The results of the phylogenetic analysis using various tree-making algorithms were very similar (data not shown). A subset of the closest phylogenetic relatives of strain NAR $01^{\mathrm{T}}$ based on the neighbour-joining method are presented in Fig. 1. A phylogenetic tree that includes all Micromonospora species with validly published names is available as Supplementary Fig. S1 in IJSEM Online.

For chemotaxonomic analyses, strain $\mathrm{NAR} 01^{\mathrm{T}}$ was grown in tryptic soy broth in flasks on a rotary shaker at 90 r.p.m. and $28^{\circ} \mathrm{C}$. Biomass was harvested, washed in distilled water and 


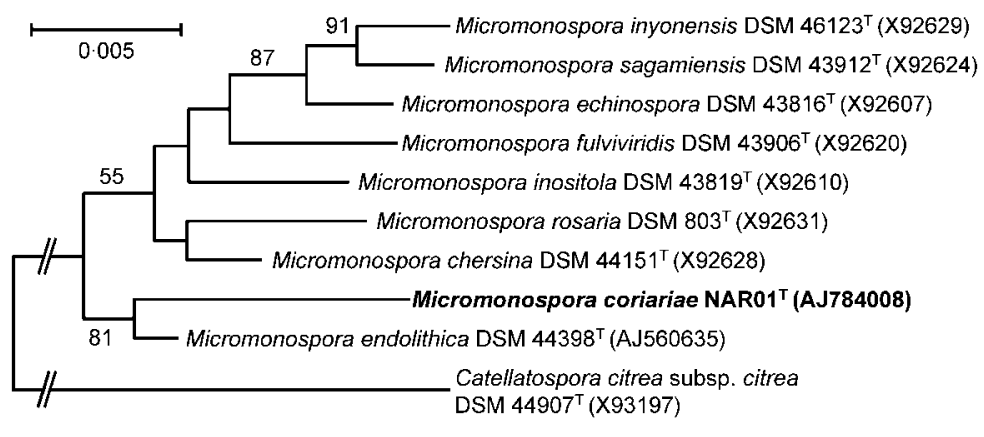

Fig. 1. Phylogenetic tree, based on 16S rRNA gene sequences, showing the relationships among phylogenetically related members of the genus Micromonospora and the novel isolate $\mathrm{NARO1}{ }^{\top}$. The tree was constructed by using a neighbour-joining analysis with distances based on the Kimura two-parameter model. Bootstrap percentages (of 1000 replicates) above $50 \%$ are shown at nodes. Bar, 5 nucleotide changes per 1000 nt. An extended version of this tree containing all species of Micromonospora is available as Supplementary Fig. S1 in IJSEM Online. freeze-dried. The chemotaxonomic analyses performed included diaminopimelic acid determination in whole-cell hydrolysates, using TLC on cellulose (modified method of Hasegawa et al., 1983; Rhuland et al., 1955). Whole-cell sugars were analysed according to Staneck \& Roberts (1974). Menaquinones were extracted and purified using the method of Minnikin et al. (1984) and then analysed by HPLC (model 1100; Hewlett Packard). Polar lipids were extracted and identified by two-dimensional TLC (Minnikin et al., 1984). Cellular fatty acid methyl esters were prepared from cells grown for $24 \mathrm{~h}$ on trypticase soy agar (Schröder et al., 1997).

The chemotaxonomic markers found were in agreement with the results of phylogenetic analyses, confirming the classification of strain $\mathrm{NAR}^{\mathrm{T}} \mathrm{I}^{\mathrm{T}}$ within the genus Micromonospora, and also revealing differences at the species level. The novel isolate contained meso-diaminopimelic acid, while the whole-cell sugars detected were arabinose, glucose, mannose, ribose and xylose. Specifically, the presence of glucose and mannose and the absence of galactose and rhamnose distinguished the novel isolate from $M$. endolithica DSM $44398^{\mathrm{T}}$. Other differences in sugar composition between $\mathrm{NAR}^{\mathrm{T}} \mathrm{1}^{\mathrm{T}}$ and its closest phylogenetic neighbours are given in Table 1. Large amounts of menaquinone MK$10\left(\mathrm{H}_{4}\right)(>60 \%)$ and smaller amounts of MK-9 $\left(\mathrm{H}_{4}\right)$ and MK-10 $\left(\mathrm{H}_{6}\right)$ were detected. The polar lipid composition included phosphatidylglycerol, phosphatidylinositol and phosphatidylethanolamine, a profile that corresponds to Lechevalier's phospholipid pattern II (Lechevalier et al., 1977). Some unidentified glycolipids were also detected. Significant amounts of iso-15:0 (24\%), iso-16:0 (17\%), $17: 0(10 \%)$ and 10-methyl-17:0 (16\%) were detected in the cellular fatty acid profile of $\mathrm{NAR}^{\mathrm{T}} \mathrm{I}^{\mathrm{T}}$. The detailed fatty acid composition of strain $\mathrm{NAR} 01^{\mathrm{T}}$ is presented in Supplementary Table S1 (available in IJSEM Online). The $\mathrm{G}+\mathrm{C}$ content, determined using the thermal melting method (Mandel \& Marmur, 1968), was found to be $70 \cdot 2 \mathrm{~mol} \%$.

Phenotypic characteristics were studied using several standard methods. Catalase and oxidase activities were determined as described previously (Trujillo et al., 2006). The hydrolysis of arbutin, aesculin, casein, gelatin, Tweens
20 and 80, starch, tyrosine, urea and xylan was investigated as described by Trujillo et al. (2005), using SA1 agar as a basal medium. Tests for the utilization of various substrates as sole carbon and energy sources were performed according to Williams et al. (1983). The temperature range for growth and the $\mathrm{NaCl}$ tolerance were recorded using ISP 2 agar as the basal medium. SA1 agar supplemented with appropriate buffer systems was used for $\mathrm{pH}$-tolerance studies. Enzyme activities for strains NAR01 ${ }^{\mathrm{T}}, M$. endolithica DSM $44398^{\mathrm{T}}$, M. chersina DSM $44151^{\mathrm{T}}$ and Micromonospora echinospora DSM $43816^{\mathrm{T}}$ were performed using API ZYM and API Coryne kits (bioMérieux) according to the manufacturer's instructions.

The novel isolate, NAR $01^{\mathrm{T}}$, presented a phenotypic profile that clearly distinguished it from its closest phylogenetic neighbours (Table 1). An important difference found between NAR01 $1^{\mathrm{T}}$ and its closest neighbour, M. endolithica DSM $44398^{\mathrm{T}}$, was the capacity of the latter organism to grow in $7 \% \mathrm{NaCl}\left(\mathrm{NAR} 01^{\mathrm{T}}\right.$ tolerated concentrations of only $1 \%$ ). Xylan degradation also differentiated $\mathrm{NAR}^{\mathrm{T}} 1^{\mathrm{T}}$ from $M$. endolithica DSM $44398^{\mathrm{T}}$, M. chersina DSM $44151^{\mathrm{T}}$ and Micromonospora inositola DSM 43819 ${ }^{\mathrm{T}}$. Furthermore, $\mathrm{NAR}_{0} 1^{\mathrm{T}}$ was negative for tyrosine hydrolysis whereas $M$. endolithica DSM $44398^{\mathrm{T}}$ and Micromonospora rosaria DSM $803^{\mathrm{T}}$ were positive. Additional phenotypic data are given in the species description.

Finally, DNA-DNA hybridizations between $\mathrm{NAR}^{\mathrm{T}}{ }^{\mathrm{T}}, M$. endolithica DSM $44398^{\mathrm{T}}$ and M. chersina DSM $44151^{\mathrm{T}}$ were carried out to confirm the species status of the novel isolate. DNA was isolated and purified on hydroxyapatite according to the method of Cashion et al. (1977). Hybridization measurements were obtained according to the spectrophotometric method of De Ley et al. (1970), with the modification of Huß et al. (1983). DNA-DNA reassociation values of 11.5 and $25 \%$ were obtained between $\mathrm{NAR} 1^{\mathrm{T}}$ and M. endolithica DSM $44398^{\mathrm{T}}$ and M. chersina DSM $44151^{\mathrm{T}}$, respectively. These percentages fall well below the $70 \%$ value recommended for defining genomic species (Wayne et al., 1987). Furthermore, they support the idea that Micromonospora strains represent individual genospecies when 16S rRNA gene sequence values are below $99 \%$ (Kroppenstedt et al., 2005). 
Strain NAR $01^{\mathrm{T}}$ can be clearly differentiated from currently described Micromonospora species on the basis of the genotypic and phenotypic data. Thus, isolate NAR $01^{\mathrm{T}}$ represents the type strain of a novel species, for which we propose the name Micromonospora coriariae sp. nov.

\section{Description of Micromonospora coriariae sp. nov.}

Micromonospora coriariae (co.ri.a' ri.ae. N.L. gen. n. coriariae of Coriaria, pertaining to the isolation of the type strain from root nodules of Coriaria myrtifolia).

Gram-positive, chemo-organotrophic, aerobic actinobacterium. Colonies are intensely orange, raised and folded. Welldeveloped substrate mycelium carrying single spores mostly on the tips of the hyphae. Aerial mycelium is absent. Diffusible pigments are not produced. $\mathrm{pH}$ range for growth is 7-9; does not grow below $\mathrm{pH} 6 \cdot 5$. Optimum growth temperature is $28{ }^{\circ} \mathrm{C}$. Oxidase- and catalase-positive. Arbutin, aesculin, casein, gelatin, starch and Tween 80 are degraded, but Tween 20, tyrosine and urea are not. The following are used as carbon sources: alanine, arabinose, arginine, cellobiose, fructose, gluconate, glucose, histidine, mannose, melibiose, pyruvate, raffinose, rhamnose, salicin, serine, starch, trehalose and xylose. The following substrates are not used as carbon sources: ascorbic acid, meso-erythritol, galactose, glutaric acid, lysine, melezitose, proline, propionic acid, quinic acid, sorbitol, sorbose, sucrose, tyrosine, valine and xylitol. Positive enzymic reactions are obtained for the following: acid phosphatase, alkaline phosphatase, cystine arylamidase, esterase (C8), leucine arylamidase, $\alpha$-galactosidase, $\beta$-galactosidase, $\alpha$-glucosidase, $\beta$-glucosidase, $N$-acetyl$\beta$-glucosaminidase, pyrazinamidase and valine arylamidase. Negative reactions are obtained for the following enzymes: $\alpha$ chymotrypsin, $\alpha$-fucosidase, $\beta$-glucuronidase, $\alpha$-mannoside, naphthol-AS-BI-phosphohydrolase and pyrrolidonyl arylamidase. Other physiological and biochemical characteristics are shown in Table 1. Whole-cell sugars present are glucose, xylose, arabinose, mannose and ribose. The major menaquinone is $\mathrm{MK}-10\left(\mathrm{H}_{4}\right)$.

The type strain, NAR01 ${ }^{\mathrm{T}}\left(=\mathrm{DSM} 44875^{\mathrm{T}}=\mathrm{LMG} 23557^{\mathrm{T}}\right)$, was isolated from root nodules of Coriaria myrtifolia.

\section{Acknowledgements}

We would like to thank Dr J. P. Euzéby for his help with the nomenclature. We also acknowledge the excellent technical assistance of Mrs G. Pötter and other members of DSMZ staff. This work was financed by the Ministerio de Educación y Ciencia (Spain). M.E.T. acknowledges financial support from the EU under the BIOREMAT programme.

\section{References}

Cashion, P., Holder-Franklin, M. A., McCully, J. \& Franklin, M. (1977). A rapid method for the base ratio determination of bacterial DNA. Anal Biochem 81, 461-466.
Coombs, J. T. \& Franco, C. M. M. (2003). Isolation and identification of actinobacteria from surface-sterilized wheat roots. Appl Environ Microbiol 69, 5603-5608.

De Ley, J., Cattoir, H. \& Reynaerts, A. (1970). The quantitative measurement of DNA hybridization from renaturation rates. Eur $J$ Biochem 12, 133-142.

De Soete, G. (1983). A least squares algorithm for fitting additive trees to proximity data. Psychometrika 48, 621-663.

Doetsch, R. N. (1981). Determinative methods of light microscopy. In Manual of Methods for General Bacteriology, pp. 21-33. Edited by P. Gerdhardt, R. G. E. Murray, R. N. Costilow, E. W. Nester, W. A. Wood, N. R. Krieg \& G. B. Phillips. Washington, DC: American Society for Microbiology.

Fitch, W. M. (1971). Toward defining the course of evolution: minimum change for a specific tree topology. Syst Zool 20, 406-416.

Hasegawa, T., Takizawa, M. \& Tanida, S. (1983). A rapid analysis for chemical grouping of aerobic actinomycetes. J Gen Appl Microbiol 29, 319-322.

Hirsch, P., Mevs, U., Kroppenstedt, R. M., Schumann, P. \& Stackebrandt, E. (2004). Cryptoendolithic actinomycetes from antarctic sandstone rock samples: Micromonospora endolithica sp. nov. and two isolates related to Micromonospora coerulea Jensen 1932. Syst Appl Microbiol 27, 166-174.

Huß, V. A. R., Festl, H. \& Schleifer, K. H. (1983). Studies on the spectrophotometric determination of DNA hybridisation from renaturation rates. Syst Appl Microbiol 4, 184-192.

Jones, K. L. (1949). Fresh isolates of actinomycetes in which the presence of sporogeneous aerial mycelia is a fluctuating characteristic. J Bacteriol 57, 141-146.

Kawamoto, I. (1989). Genus Micromonospora Ørskov 1923, $147^{\mathrm{AL}}$. In Bergey's Manual of Systematic Bacteriology, vol. 4, pp. 2442-2450. Edited by S. T. Williams, M. E. Sharpe \& J. G. Holt. Baltimore: Williams \& Wilkins.

Kroppenstedt, R. M., Mayilraj, S., Wink, J. M., Kallow, W., Schumann, P., Secondini, C. \& Stackebrandt, E. (2005). Eight new species of the genus Micromonospora, Micromonospora citrea sp. nov., Micromonospora echinaurantiaca sp. nov., Micromonospora echinofusca sp. nov., Micromonospora fulviviridis sp. nov., Micromonospora inyonensis sp. nov., Micromonospora peucetia sp. nov., Micromonospora sagamiensis sp. nov., and Micromonospora viridifaciens sp. nov. Syst Appl Microbiol 28, 328-339.

Kumar, S., Tamura, K., Jakobsen, I.-B. \& Nei, M. (2001). MEGA2: molecular evolutionary genetics analysis software. Bioinformatics $\mathbf{1 7}$, 1244-1245.

Lechevalier, M. P., De Bièvre, C. \& Lechevalier, H. (1977). Chemotaxonomy of aerobic actinomycetes: phospholipid composition. Biochem Syst Ecol 5, 249-260.

Mandel, M. \& Marmur, J. (1968). Use of ultraviolet absorbance temperature profile for determining the guanine plus cytosine content of DNA. Methods Enzymol 12B, 195-206.

Minnikin, D. E., O'Donnell, A. G., Goodfellow, M., Alderson, G., Athalye, M., Schaal, K. \& Parlett, J. H. (1984). An integrated procedure for extracting bacterial isoprenoid quinones and polar lipids. J Microbiol Methods 2, 233-241.

Ørskov, J. (1923). Investigation into the Morphology of the Ray Fungi. Copenhagen: Levin and Munksgaard.

Rhuland, L. E., Work, E., Denman, R. F. \& Hoare, D. S. (1955). The behaviour of the isomers of $\alpha, \varepsilon$-diaminopimelic acid on paper chromatograms. J Am Chem Soc 77, 4844-4846.

Rivas, R., Sánchez, M., Trujillo, M. E., Zurdo-Piñeiro, J. L., Mateos, P. F., Martínez-Molina, E. \& Velázquez, E. (2003). Xylanimonas cellulosilytica gen. nov., sp. nov., a xylanolytic bacterium isolated 
from a decayed tree (Ulmus nigra). Int J Syst Evol Microbiol 53, 99-103.

Saitou, N. \& Nei, M. (1987). The neighbor-joining method: a new method for reconstructing phylogenetic trees. Mol Biol Evol 4, 406-425.

Schröder, K.-H., Naumann, I., Kroppenstedt, R. M. \& Reischl, U. (1997). Mycobacterium hassiacum sp. nov., a new rapidly growing thermophilic mycobacterium. Int J Syst Bacteriol 47, 86-91.

Staneck, J. L. \& Roberts, G. D. (1974). Simplified approach to the identification of aerobic actinomycetes by thin layer chromatography. Appl Microbiol 28, 226-231.

Thawai, C., Tanasupawat, S., Itoh, T., Suwanborirux, K., Suzuki, K. \& Kudo, T. (2005a). Micromonospora eburnea sp. nov., isolated from a Thai peat swamp forest. Int J Syst Evol Microbiol 55, 417-422.

Thawai, C., Tanasupawat, S., Itoh, T., Suwanborirux, K. \& Kudo, T. (2005b). Micromonospora siamensis sp. nov., isolated from Thai peat swamp forest. J Gen Appl Microbiol 51, 229-234.

Trujillo, M. E., Fernández-Molinero, C., Velázquez, E., Kroppenstedt, R. M., Schumann, P., Mateos, P. F. \& Martínez-Molina, E. (2005).
Micromonospora mirobrigensis sp. nov. Int J Syst Evol Microbiol 55, 877-880.

Trujillo, M. E., Kroppenstedt, R. M., Schumann, P. \& MartínezMolina, E. (2006). Kribbella lupini sp. nov., isolated from the roots of Lupinus angustifolius. Int J Syst Evol Microbiol 56, 407-411.

Valdés, M., Pérez, N.-O., Estrada-de los Santos, P., CaballeroMellado, J., Peña-Cabriales, J. J., Normand, P. \& Hirsch, A. M. (2005). Non-Frankia actinomycetes isolated from surface-sterilized roots of Casuarina equisetifolia fix nitrogen. Appl Environ Microbiol 71, 460-466.

Vincent, J. M. (1970). The cultivation, isolation and maintenance of rhizobia. In A Manual for the Practical Study of Root Nodule Bacteria, pp. 1-13. Edited by J. M. Vincent. Oxford: Blackwell Scientific.

Wayne, L. G., Brenner, D. J., Colwell, R. R. \& 9 other authors (1987). International Committee on Systematic Bacteriology. Report of the ad hoc committee on reconciliation of approaches to bacterial systematics. Int J Syst Bacteriol 37, 463-464.

Williams, S. T., Goodfellow, M., Alderson, G., Wellington, E. M. H., Sneath, P. H. A. \& Sackin, M. J. (1983). Numerical classification of Streptomyces and related genera. J Gen Microbiol 129, 1743-1813. 